\title{
Toll-Like Receptors are critical in controlling colonic inflammation and cancer
}

\author{
Hui Xiao ${ }^{1,2^{*}}$, Weiguo Yin ${ }^{2}$, Mohammed A Khan ${ }^{3}$, Muhammet F Gulen ${ }^{2}$, Bruce A Vallance ${ }^{3}$, Xiaoxia Li ${ }^{2}$ \\ From Institut Pasteur International Network Annual Scientific Meeting \\ Hong Kong. 22-23 November 2010
}

Despite the presence of large number and diverse populations of commensal microbes, gut mucosa has evolved to maintain "microbial-tolerance", which is critically regulated by well-controlled Toll-like receptor (TLR) signaling. Deregulated TLR signaling has been linked to the pathogenesis of inflammatory bowel disease and colon cancer; however, the underlying mechanisms need to be further defined. In this study, we uncovered that lack of SIGIRR, a negative regulator for TLR and IL-1R signaling, led to increased genetic instability and $\mathrm{LOH}$ of $A p c$, resulting in spontaneous colonic polyposis in $\mathrm{Apc}^{\mathrm{min} /+} / \mathrm{Sigirr}^{-1-}$ mice. Importantly, elevated colonic tumorigenesis in $\mathrm{Apc}^{\mathrm{min} /+} / \mathrm{Sigirr}^{-/-}$mice is dependent on the presence of commensal microbes in gut, implicating a critical role for TLR signaling in tumorigenesis. Furthermore, we demonstrated that SIGIRR-modulated TLR-mediated tumor initiation is mainly through the activation of the Akt-mTOR axis, which promotes cell cycle progression through its impact on posttranscriptional control of the key cell cycle regulators (Cyclins, c-Myc and cdk2). Moreover, abrogation of mTOR pathway by rapamycin prevented microadenoma and polyps formation in $\mathrm{Apc} \mathrm{min} /+^{\mathrm{m}} / \mathrm{Sigirr}^{-/-}$mice, providing new insights into treating human cancers. In addition, augmented production of proinflammatory cytokines, such as IL-6 and IL-23, further promoted tumor growth in $A p c^{\text {min } /+} /$ Sigirr $^{-1-}$ mice. Epithelium specific re-expression of SIGIRR in $\mathrm{Apc}^{\mathrm{min} /+} / \mathrm{Sigirr}^{-/-}$mice ameliorated intestinal tumorigenesis. In summary, this study indicates that SIGIRR is a critical tumor suppressor that controls tumorigenesis by inhibiting TLR-induced mTOR and NFkB pathways in colonic epithelium.

\footnotetext{
* Correspondence: huixiao@sibs.ac.cn

'Unit of Immune Signaling and Regulation, Institut Pasteur of Shanghai, Shanghai 200025, PR China

Full list of author information is available at the end of the article
}

\section{Author details}

'Unit of Immune Signaling and Regulation, Institut Pasteur of Shanghai, Shanghai 200025, PR China. ²Department of Immunology, Cleveland Clinic Foundation, Cleveland, OH 44195, USA. ${ }^{3}$ Division of Gastroenterology, University of British Columbia and BC Children's Hospital, Vancouver, BC V6T 1Z4, Canada.

Published: 10 January 2011

\section{doi:10.1186/1753-6561-5-S1-P87}

Cite this article as: Xiao et al:: Toll-Like Receptors are critical in controlling colonic inflammation and cancer. BMC Proceedings 20115 (Suppl 1):P87.
Submit your next manuscript to BioMed Central and take full advantage of:

- Convenient online submission

- Thorough peer review

- No space constraints or color figure charges

- Immediate publication on acceptance

- Inclusion in PubMed, CAS, Scopus and Google Scholar

- Research which is freely available for redistribution
() Biomed Central
C Biomed Central

(c) 2011 Xiao et al; licensee BioMed Central Ltd. This is an open access article distributed under the terms of the Creative Commons Attribution License (http://creativecommons.org/licenses/by/2.0), which permits unrestricted use, distribution, and reproduction in any medium, provided the original work is properly cited. 